\title{
Population biology of sympatric species of Caprella (Amphipoda: Caprellidae) in a tropical algal bed
}

\author{
Daniela Rejane de Paula ${ }^{1}$, Karla Vanessa Souza Cunha ${ }^{1}$, Isabela Corsini Pereira Garcia ${ }^{1}$, \\ Samara de Paiva Barros-Alves ${ }^{2}$, Giuliano Buzá Jacobucci ${ }^{1}$ \\ ${ }^{1}$ Instituto de Biologia, Universidade Federal de Uberlândia, Rua Ceará, Bloco 2D, CEP 38400-902, Uberlândia, Minas \\ Gerais, Brazil. \\ (DRP) E-mail: danielabiologia@ hotmail.com. ORCID iD: https://orcid.org/0000-0001-9844-2488 \\ (KVSC) E-mail: karlavscunha@gmail.com. ORCID iD: https://orcid.org/0000-0002-5060-748X \\ (ICPG) E-mail: icorsinipg@gmail.com. ORCID iD: https://orcid.org/0000-0002-4443-8624 \\ (GBJ) (Corresponding author) E-mail: jacobucci@ufu.br. ORCID iD: https://orcid.org/0000-0001-7567-4710 \\ ${ }^{2}$ Departamento de Ciências Biológicas, Universidade do Estado de Minas Gerais, Rua Vereador Geraldo Moisés da Silva, \\ s/n, CEP 38302-192, Ituiutaba, Minas Gerais, Brazil. \\ (SPB-A) E-mail: barros_samara@hotmail.com. ORCID iD: https://orcid.org/0000-0001-7216-3421
}

\begin{abstract}
Summary: The population biology of the three sympatric species of caprellids (Caprella danilevskii, C. equilibra and C. scaura) associated with a Sargassum bed was studied in the northern coast of São Paulo state, Brazil. Samplings were carried out monthly from October 2010 to February 2012. In each month, 25 fronds of Sargassum were randomly collected through snorkelling. The caprellids were identified, counted, classified by sex and separated into size classes. Caprella danilevskii was the most abundant species, with 14939 specimens recorded. The body size of males was larger than that of females for $C$. danilevskii and $C$. equilibra, and the sex ratio was skewed toward males for all species. The size-frequency distribution was polymodal for $C$. danilevskii and $C$. scaura and bimodal for $C$. equilibra. Mature males of $C$. scaura and C. equilibra were recorded in all size classes. The last size classes (from 8.3-9.4 to 12.7-13.8 mm) were dominated by mature males. Mature and ovigerous females were more frequent in intermediate size classes. Significant temporal variations were recorded for the three species with higher densities in spring and summer that are related to higher algal biomass; but other environmental factors are certainly important for explaining caprellid density variation.
\end{abstract}

Keywords: Crustacea; Caprellidae; population structure; Sargassum; brown alga; phytal.

Biología de poblaciones de especies simpátricas de Caprella (Amphipoda: Caprellidae) en un bosque de algas tropicales

Resumen: Se estudió la biología poblacional de las tres especies simpátricas de caprélidos (Caprella danilevskii, C. equilibra y C. scaura) asociadas a un lecho de Sargassum en la costa norte del estado de São Paulo, Brasil. Los muestreos se realizaron mensualmente desde octubre de 2010 hasta febrero de 2012 . En cada mes, se recolectaron al azar 25 frondas de Sargassum a través de snorkel. Los caprélidos fueron identificados, contados, clasificados por sexo y separados en clases de tamaño. Caprella danilevskii fue la especie más abundante, con 14939 ejemplares registrados. El tamaño corporal de los machos fue mayor que el de las hembras para $C$. danilevskii y $C$. equilibra y la proporción de sexos se inclinó hacia los machos para todas las especies. La distribución de frecuencia de tamaño fue polimodal para $C$. danilevskii y $C$. scaura y bimodal para $C$. equilibra. Se registraron machos maduros de $C$. scaura y $C$. equilibra en todas las clases de tamaño. Las últimas clases de tamaño (de 8,3-9,4 a 12,7-13,8 mm) estuvieron dominadas por machos maduros. Las hembras maduras y ovígeras fueron más frecuentes en clases de tamaño intermedio. Se registraron variaciones temporales significativas para las tres especies con mayores densidades en primavera y verano que están relacionadas con una mayor biomasa de algas; pero otros factores ambientales son ciertamente importantes para explicar la variación de la densidad de los caprélidos.

Palabras clave: Crustacea; Caprellidae; estructura poblacional; Sargassum; alga marrón; fital.

Citation/Como citar este artículo: de Paula D.R., Souza Cunha K.V., Garcia I.C.P., Barros-Alves S.P., Jacobucci G.B. 2021. Population biology of sympatric species of Caprella (Amphipoda, Peracarida) in a tropical algal bed. Sci. Mar. 85(1): 39-47. https://doi.org/10.3989/scimar.05065.004

Editor: M.G. Mazzocchi.

Received: August 20, 2020. Accepted: November 10, 2020. Published: March 31, 2021.

Copyright: (C) 2021 CSIC. This is an open-access article distributed under the terms of the Creative Commons Attribution 4.0 International (CC BY 4.0) License. 


\section{INTRODUCTION}

The family Caprellidae includes more than 400 described species (Ahyong et al. 2011) that inhabit a high diversity of substrates, including macroalgae, hydroids, sponges, ascidians, anthozoans, bryozoans, seagrasses and sediment from marine shallow coastal areas to deep water environments (Guerra-García 2001, González et al. 2008, Cunha et al. 2018). The morphological features of caprellids favour clinging onto the substrates, and they can be passively transported by floating natural and artificial debris such as macroalgae and fishing buoys (Thiel et al. 2003). This capacity allows some caprellid species to invade marine areas, with still poorly known effects in marine environments (Martínez and Adarraga 2008, Boos et al. 2011, Ros et al. 2015)

In the last two decades, some studies involving caprellid diet (Guerra-García and Figueroa 2009) and distribution patterns (González et al. 2008, Vázquez-Luis et al. 2009) have been performed, but reproductive and population studies of these crustaceans are still few in number (Bynum 1978, Sconfietti and Lupari 1995, Prato et al. 2013), particularly in tropical areas (Jacobucci et al. 2002, De Paula et al. 2016). Knowledge on population attributes is important because they provide information about ecological stability of populations, including temporal variation in abundance, size structure, birth rates and mortality (Hutchinson 1981, Santos et al. 1995). This basic information is important to support applied studies such as their use as pollution bioindicators and even in cultivation as a food source in aquaculture (Guerra-García and García-Gómez 2001, Ohji et al. 2002, Guerra-García et al. 2016).

Caprellid amphipods, among other crustaceans, are quite frequent inhabitants of brown algae of the genus Sargassum C. Agardh, 1820 in temperate and tropical areas (Imada and Kikuchi 1984, Martin-Smith 1993, Jacobucci et al. 2002) and are an important trophic link between primary producers and higher trophic levels (Woods 2009). In shallow coastal areas of southeastern Brazil, these algal beds are quite common, representing over $80 \%$ of the biomass in some areas of the states of São Paulo and Rio de Janeiro (Paula and Oliveira-Filho 1980). In this region, most caprellids living in Sargassum beds belong to the genus Caprella Lamarck, 1801, with five species already recorded (Jacobucci and Leite 2002, Jacobucci et al. 2009).

Caprella danilevskii Czerniavski, 1868, C. equilibra Say, 1818 and C. scaura Templeton, 1836 are species with wide global distribution that occur in tropical and temperate coastal areas of various continents, suggesting that they have high levels of phenotypic plasticity and invasion potential (Mauro and Serejo 2015). Caprella scaura specifically is a successful invader in the Mediterranean Sea, spreading over coastal areas of Europe and North Africa in the last few decades (Guerra-García et al. 2011, Ros et al. 2014, Servello et al. 2019). These species occur in sympatry in Sargassum beds in the northern coast of São Paulo state (Jacobucci et al. 2009).
As they are congeneric species, they share similar ecological features and could compete for resources. Although most of their diet consists of detritus, which is an abundant food resource in algal beds, in some periods caprellid densities of some species exceed 5 ind. $\mathrm{g}^{-1}$ of Sargassum (Jacobucci et al. 2018). In these conditions, because Sargassum epifauna is remarkably diverse and abundant, the algal substrate can be a limited resource. Sargassum epiphytic hydrozoans could also be a limited substrate. They are particularly important for juvenile caprellids, contributing a finely branched environment that is more suitable for their small pereopods to grasp (Cunha et al. 2018).

Regional information about the biology of $\mathrm{Ca}$ prella danilevskii, C. equilibra and C. scaura can provide data for comparison with that of populations of other coastal areas of the world. This work aims to evaluate the population biology of these three sympatric species that occur in a Sargassum bed in the northern coast of São Paulo state, Brazil.

\section{MATERIALS AND METHODS}

\section{Study site and sampling methods}

Collections were carried out in Lázaro Beach, located in Fortaleza Inlet $\left(23^{\circ} 30^{\prime} \mathrm{S} 45^{\circ} 08^{\prime} \mathrm{W}\right)$ in Ubatuba, a municipality on the southeastern coast of Brazil (Fig. 1). The beach is bordered by rocky shores with dense cover of the brown alga Sargassum cymosum C. Agardh, 1820 and is moderately exposed to wave action (Széchy and Paula 2000). This area was selected for the present study because

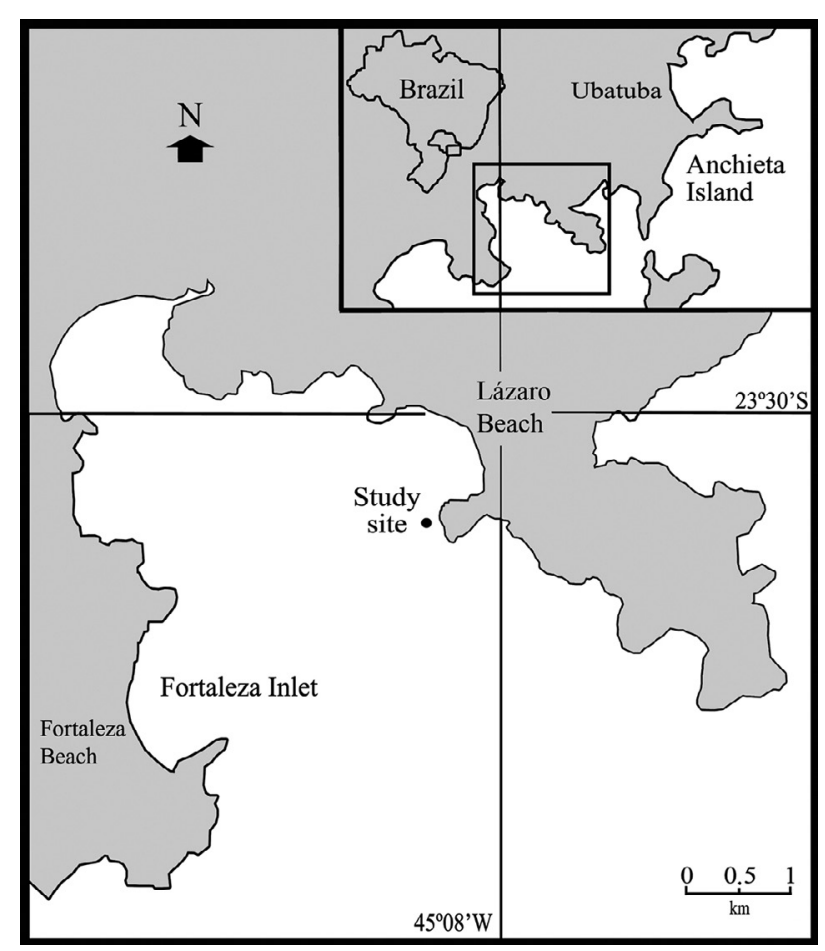

Fig. 1. - Map of Brazil with details of the Lázaro Beach in the Ubatuba region, southeastern Brazil (Adapted from Garcia et al., 2019). 
caprellids are very abundant, with densities higher than 20 ind./g of dry weight of S. cymosum (Jacobucci et al. 2002). Specimens were collected monthly from October 2010 to February 2012 in a slopping rocky shore area from 2.5 to $3.0 \mathrm{~m}$ depth from the surface. In each month, 25 fronds of $S$. cymosum were randomly collected through snorkelling. The fronds of $S$. cymosum were removed from the substrate with a spatula and individually covered with fabric bags $(0.2 \mathrm{~mm}$ mesh size) (Jacobucci et al. 2002). This technique was previously used by Takeuchi et al. (1987) and proved to be efficient, and the mesh size was suitable to retain the caprellids. The bags with algae were stored in glass jars, fixed with $5 \%$ formaldehyde and transported to the laboratory.

\section{Laboratory procedure}

In the laboratory, each frond was washed with freshwater to remove the associated epifauna. This process was carried out three times to increase collection efficiency. Sargassum cymosum fronds were dried at $60^{\circ} \mathrm{C}$ for $48 \mathrm{~h}$ and then weighed to determine the dry weight (biomass) of algae. The removed epifauna was filtered on a $0.2 \mathrm{~mm}$ sieve, placed into labelled jars and preserved in $70 \%$ ethanol for later taxonomic identification. The caprellids were identified to species level (Lacerda and Masunari 2011) under a stereomicroscope (Bel Photonics and Nikon SMZ 754T). Caprellid density was calculated as the total number of recorded individuals of a given species divided by the total Sargassum dry weight (g), expressed as ind. $\mathrm{g}^{-1}$.

Sex determination was performed for all caprellids, using adapted methods of Bynum (1978) and Takeuchi and Hirano (1991). The specimens were separated into the following demographic categories: juveniles, immature females, mature females, ovigerous females and males. Individuals smaller than the smallest female analysed in the study were classified as juveniles. Caprellids larger than this female without oostegites were classified as males and those with oostegites as females. Females were classified as immature, when they did not have bristles on oostegites; mature, when they had bristles on oostegites; and ovigerous, when showed the presence of eggs or juveniles in their brood pouch. All caprellids were measured (total length) under a stereomicroscope with an ocular micrometer with constant magnification. For each specimen, the body segments were individually measured and summed to obtain the total length (mm) (Garcia et al. 2019).

\section{Data analysis}

The model's assumptions of homoscedasticity (Levene's test) and normality (Shapiro-Wilk test) of the population size distribution were tested. The mean size of the caprellids of each species was compared between males and females by the non-parametric Mann-Whitney test $(\mathrm{p}<0.05)$ (Zar 2010). To evaluate the population biology of each species, size-frequency distributions were constructed using $1.1 \mathrm{~mm}$ (total length) intervals for both males and females. The individuals were distributed into 13 size classes, from 0.6 to $14.9 \mathrm{~mm}$ (total length). Sex ratio of each species was estimated as the quotient between the number of males and the total number of individuals in the population (males plus females) (Wilson and Hardy 2002). Deviations from a 1:1 sex ratio were tested using a binomial test $(p<0.05)$ (Wilson and Hardy 2002). Sex proportion values higher or lower than 0.5 indicated populations skewed toward males or females, respectively.

The temporal dynamics of the caprellids associated with Sargassum were evaluated by interpreting parameters of each month's samples. To verify a possible tendency of variation in density of caprellids of each species and biomass of the Sargassum fronds, a linear regression analysis was performed. Multivariate analysis was carried out considering two main periods $(\mathrm{P})$, corresponding to the following seasons, spring and summer (P1) and autumn and winter (P2), as considered also by Barros-Alves et al. (2017). This separation allowed us to test the hypothesis that the structure of organisms associated with algal beds changes seasonally.

The temporal variation was analysed to investigate whether the density of caprellid species varied over the two main periods (P1 vs. P2). For this, a non-metric multi-dimensional scaling analysis was conducted using Bray-Curtis similarity matrices. One-way crossed analyses of similarity (ANOSIM) were used a posteriori to test for significant differences in the density of caprellid species between seasons. Paired comparisons between two main periods were performed when the ANOSIM $\mathrm{R}$ value was significant $(\mathrm{p}<0.05)$ (Clarke 1993). In addition, correspondence analysis was used to evaluate the relationship between the sampling month and the density of caprellids. For this analysis, density values were used, considering each species as an independent set of data, to minimize the influence of sampling design.

\section{RESULTS}

\section{Population structure of the caprellids associated with Sargassum}

A total of 14939 specimens of Caprella danilevskii were recorded, including 2421 juveniles (16.21\%), 1498 immature females $(10.03 \%), 2703$ mature females $(18.09 \%), 750$ ovigerous females $(5.02 \%)$ and 7567 mature males $(50.65 \%)$. The size-frequency distribution analysis indicated a polymodal and non-normal distribution for the population (Kolmogorov-Smirnov; K-S=0.039, $\mathrm{p}<0.001$ ) (Fig. 2A). The mean size (mean \pm sd) recorded for the sampled population was $4.86 \pm 2.08 \mathrm{~mm}$. The body size of the smallest and largest individuals observed during the sampling period was 0.67 and $14.24 \mathrm{~mm}$, respectively. The overall sex ratio significantly differed from a 1:1 proportion and was skewed toward males (Sex ratio $=0.60$, bino- 

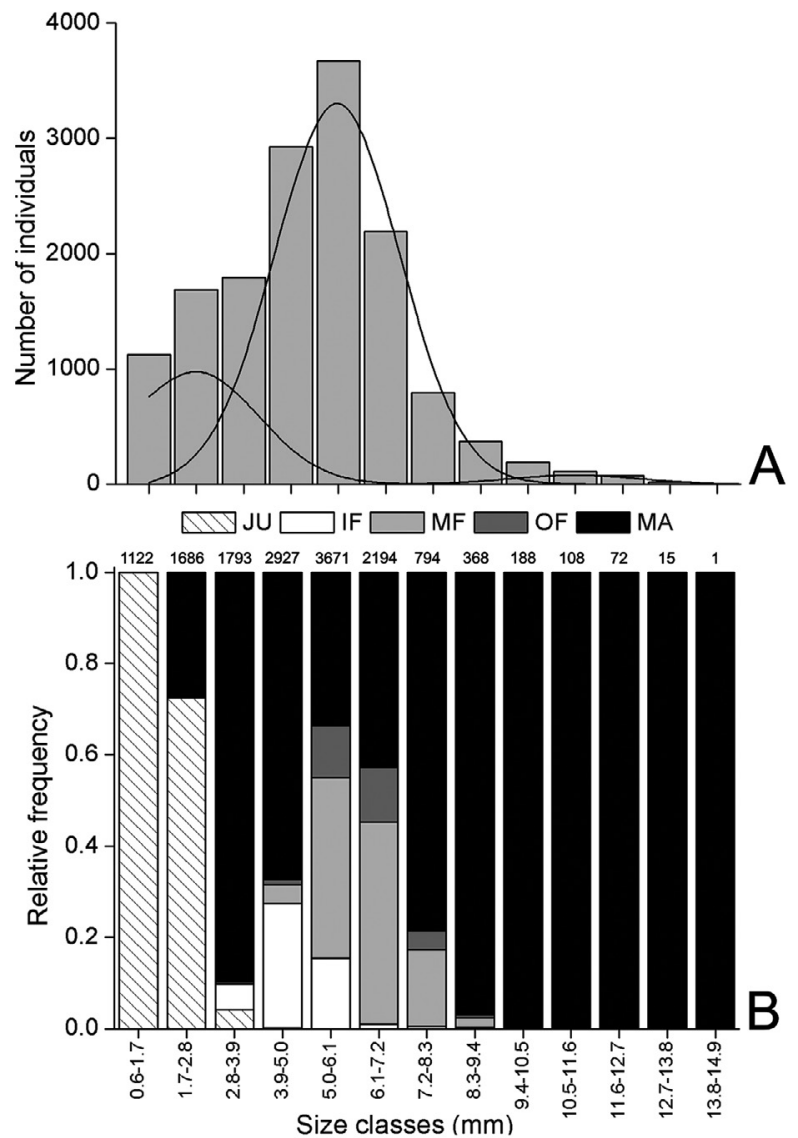

Fig. 2. - Population distribution of Caprella danilevskii in the Ubatuba region, southeastern Brazil. A, observed population distribution of the individuals collected in this study; $\mathrm{B}$, relative frequency of the individuals by size classes $(\mathrm{mm})$ and demographic categories. JU, juveniles; IF, immature females; MF, mature females; OF, ovigerous females; MA, males.

mial test; $p<0.001)$. The body size of males $(5.33 \pm 2.09$; range 1.64 to $14.24 \mathrm{~mm}$ ) was significantly larger than that of females $(5.63 \pm 0.86$; range 1.84 to $9.11 \mathrm{~mm})$ (Mann-Whitney test, $\mathrm{U}=14394022, \mathrm{p}<0.001$ ). Juveniles were distributed in the size classes from 0.6-1.7 to $2.8-3.9 \mathrm{~mm}$. Mature males were recorded in all size classes except the first. The last size classes (from 9.4-10.5 to $13.8-14.9 \mathrm{~mm}$ ) were dominated by mature males. Females were recorded in intermediate size classes (from 2.8-3.9 to 8.3-9.4 mm) (Fig. 2B).

A total of 7211 specimens of Caprella equilibra were recorded, including 1450 juveniles (20.11\%), 649 immature females $(9.00 \%), 1289$ mature females $(17.88 \%), 244$ ovigerous females $(3.38 \%)$ and 3579 mature males $(49.63 \%)$. The size-frequency distribution analysis indicated a bimodal and non-normal distribution for the population (Kolmogorov-Smirnov, $\mathrm{K}-\mathrm{S}=0.062$, $\mathrm{p}<0.001$ ) (Fig. 3A). The mean size $(\mathrm{mean} \pm \mathrm{sd})$ recorded for the sampled population was $3.67 \pm 1.78 \mathrm{~mm}$. The body size of the smallest and largest individuals observed during the sampling period was 0.66 and $12.53 \mathrm{~mm}$, respectively. The overall sex ratio significantly differed from a 1:1 proportion and was skewed toward males (sex ratio $=0.62$, binomial test; $\mathrm{p}<0.001)$. The body size of males $(4.34 \pm 0.77$;

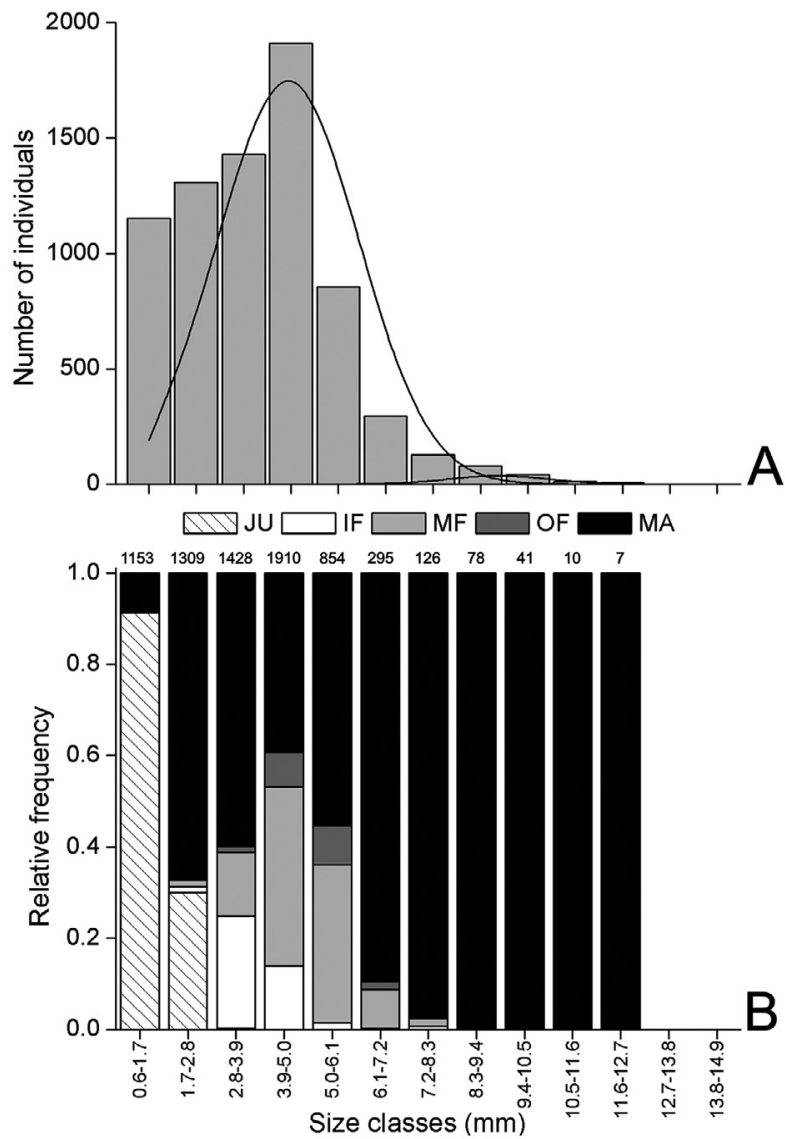

Fig. 3. - Population distribution of Caprella equilibra in the Ubatuba region, southeastern Brazil. A, observed population distribution of the individuals collected in this study; B, relative frequency of the individuals by size classes $(\mathrm{mm})$ and demographic categories. JU, juveniles; IF, immature females; MF, mature females; OF, ovigerous females; MA, males.

range 1.44 to $7.89 \mathrm{~mm}$ ) was significantly larger than that of females $(4.15 \pm 1.88$; range 1.37 to $12.53 \mathrm{~mm})$ (Mann-Whitney test, $\mathrm{U}=3190594, \mathrm{p}<0.001$ ). Juveniles were distributed in the size classes from 0.6-1.7 to 1.7$2.8 \mathrm{~mm}$. Mature males were recorded in all size classes. The last size classes (from 8.3-9.4 to 11.6-12.7 $\mathrm{mm}$ ) were dominated by mature males. Females were recorded in intermediate size classes (from 1.7-2.8 to 7.2-8.3 mm) (Fig. 3B).

A total of 1657 specimens of Caprella scaura were recorded, including 179 juveniles $(10.80 \%), 189$ immature females $(11.41 \%), 285$ mature females $(17.20 \%)$, 65 ovigerous females $(3.92 \%)$ and 939 mature males $(56.67 \%)$. The size-frequency distribution analysis indicated a polymodal and non-normal distribution for the population (Kolmogorov-Smirnov, K-S=0.053; $\mathrm{p}<0.001$ ) (Fig. 4A). The mean size (mean \pm sd) recorded for the sampled population was $5.02 \pm 2.12 \mathrm{~mm}$. The body size of the smallest and largest individual observed during the sampling period was 0.78 and 12.96 $\mathrm{mm}$, respectively. The overall sex ratio differed significantly from a 1:1 proportion and was skewed toward males (sex ratio $=0.60$, binomial test; $p<0.001$ ). The body size of males $(5.50 \pm 2.39$; range 1.60 to 12.96 $\mathrm{mm})$ and females $(5.09 \pm 0.93$; range 1.64 to $8.04 \mathrm{~mm})$ 

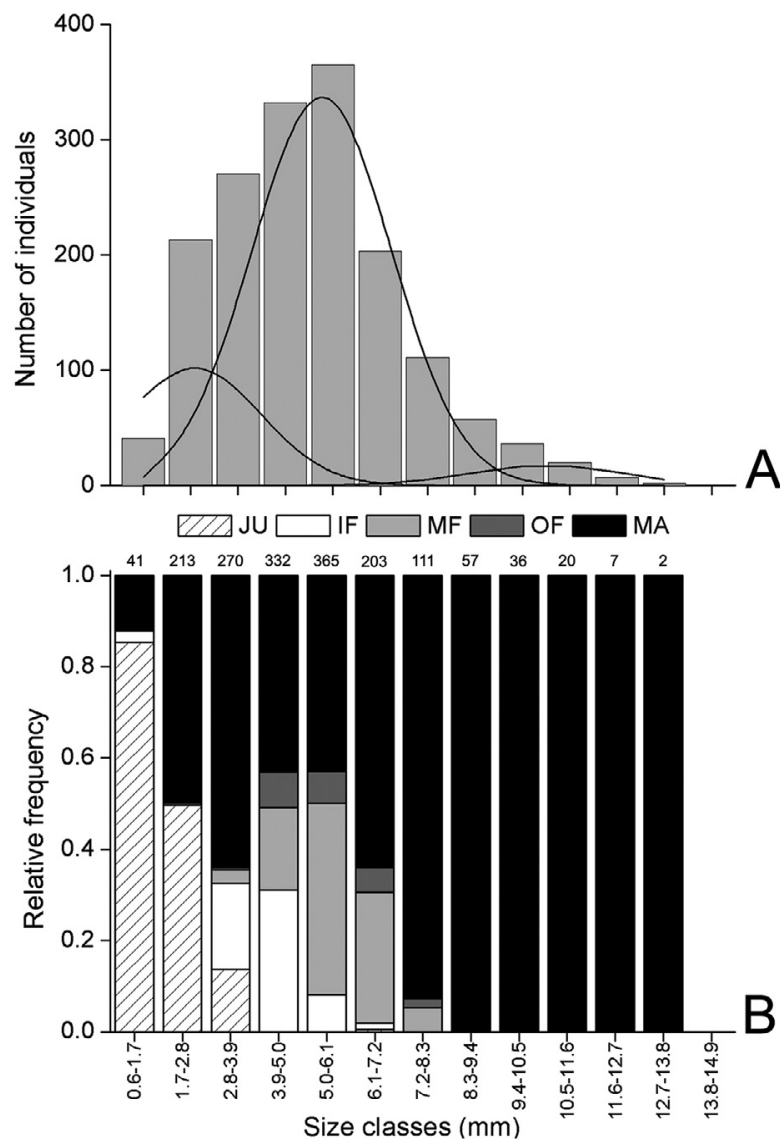

Fig. 4. - Population distribution of Caprella scaura in the Ubatuba region, southeastern Brazil. A, observed population distribution of the individuals collected in this study; $\mathrm{B}$, relative frequency of the individuals by size classes $(\mathrm{mm})$ and demographic categories. JU, juveniles; IF, immature females; MF, mature females; OF, ovigerous females; MA, males.

showed no significant difference (Mann-Whitney test; $\mathrm{U}=239064, \mathrm{p}=0.076$ ). Juveniles were distributed in the size classes from $0.6-1.7$ to $2.8-3.9 \mathrm{~mm}$. Mature males were recorded in all size classes. The last size classes (from $8.3-9.4$ to $12.7-13.8 \mathrm{~mm}$ ) were dominated by mature males. Females were recorded in the size classes from $0.6-1.7$ to $7.2-8.3 \mathrm{~mm}$ (Fig. 4B).

\section{Temporal dynamics of the caprellids associated with Sargassum}

Biomass of Sargassum ranged from $3.34 \mathrm{~g}$ in March 2011 to $14.52 \mathrm{~g}$ in December 2012 (see Fig. $5)$, with mean values $( \pm$ sd) of $7.53 \pm 3.45 \mathrm{~g}$. Population density of $C$. danilevskii ranged from 0.28 ind. $\mathrm{g}^{-1}$ in April 2011 to 28.03 ind. $\mathrm{g}^{-1}$ in January 2012, with mean $( \pm \mathrm{sd})$ of $5.00 \pm 6.93$ ind. $^{-1}$ (Fig. 5A). Population density of $C$. equilibra ranged from 0.23 ind. g $^{-1}$ in April 2011 to 7.70 ind. $\mathrm{g}^{-1}$ in January 2012, with mean $\left( \pm\right.$ sd) of $2.43 \pm 2.44$ ind.g ${ }^{-1}$ (Fig. 5B). Population density of $C$. scaura ranged from 0.10 in August 2011 to 6.03 in February 2012, with mean $( \pm \mathrm{sd})$ of $1.06 \pm 1.40$ ind. ${ }^{-1}$ (Fig. 5C). A positive correlation was observed between biomass of Sargassum and density of $C$. danilevskii (Linear regression; $\mathrm{r}^{2}=0.17$,
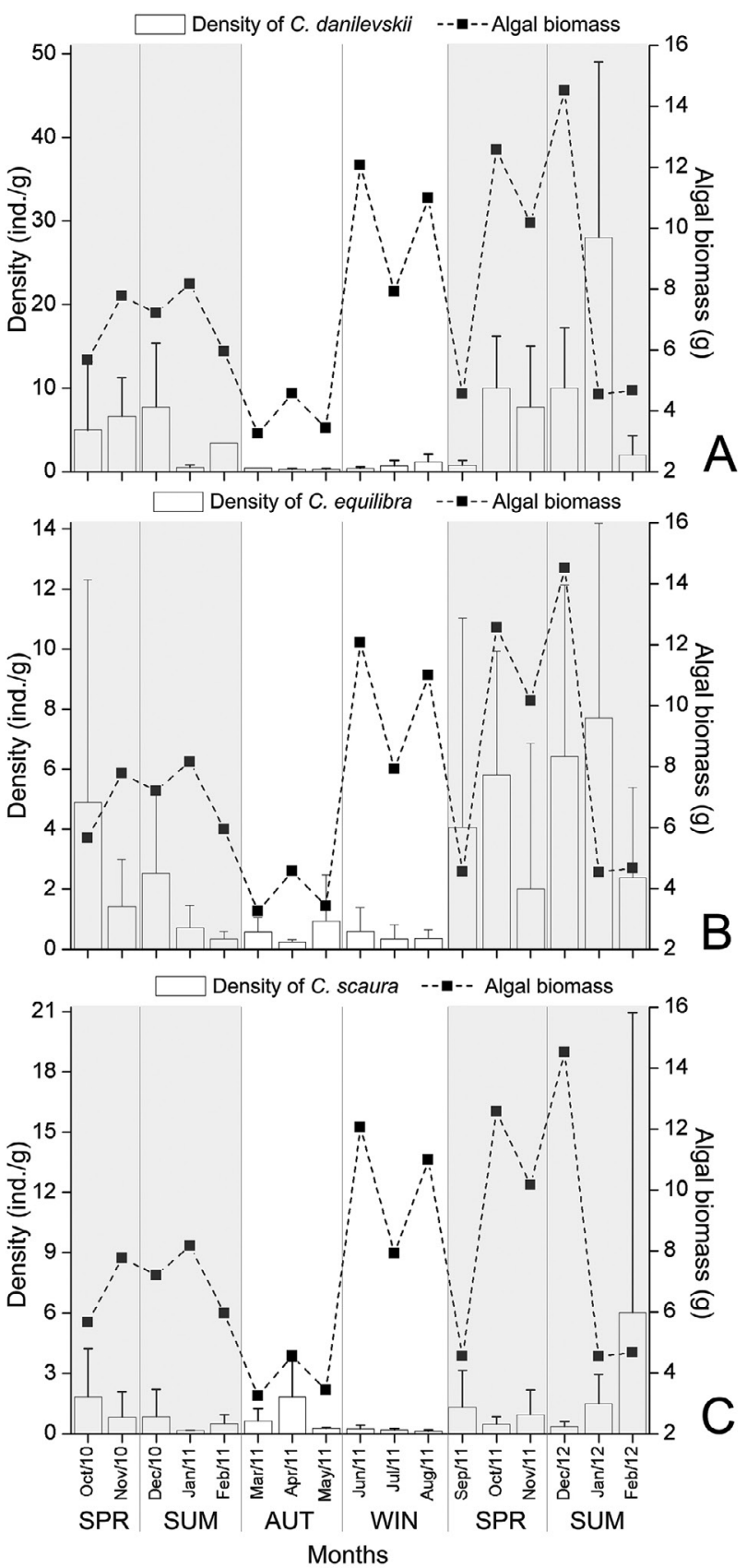

Fig. 5. - Monthly ecological parameters of the caprellids in association with Sargassum in the Ubatuba region, southeastern Brazil. Density (ind. $\mathrm{g}^{-1}$ ) of Caprella danilevskii (A), Caprella equilibra (B) and Caprella scaura (C) and the algal biomass (g). SUM, summer; AUT, autumn; WIN, winter; SPR, spring.

$\mathrm{F}=12.40, \mathrm{p}<0.01)($ Figure 5A), C. equilibra (linear regression; $\mathrm{r}^{2}=0.10, \mathrm{~F}=4.27, \mathrm{p}<0.01$ ) (Figure $5 \mathrm{~B}$ ) and $C$. scaura (Linear regression; $\mathrm{r}^{2}=0.14, \mathrm{~F}=8.91$, $\mathrm{p}<0.01$ ) (Fig. 5C).

The non-metric multi-dimensional scaling ordination derived from caprellids recorded two groups, as seen in Figure 6A. ANOSIM indicated a significant difference in the density of the caprellids between the two analysed groups (spring-summer vs. autumn-winter) (ANOSIM, $\mathrm{R}=0.644, \mathrm{p}=0.001$; Fig. 

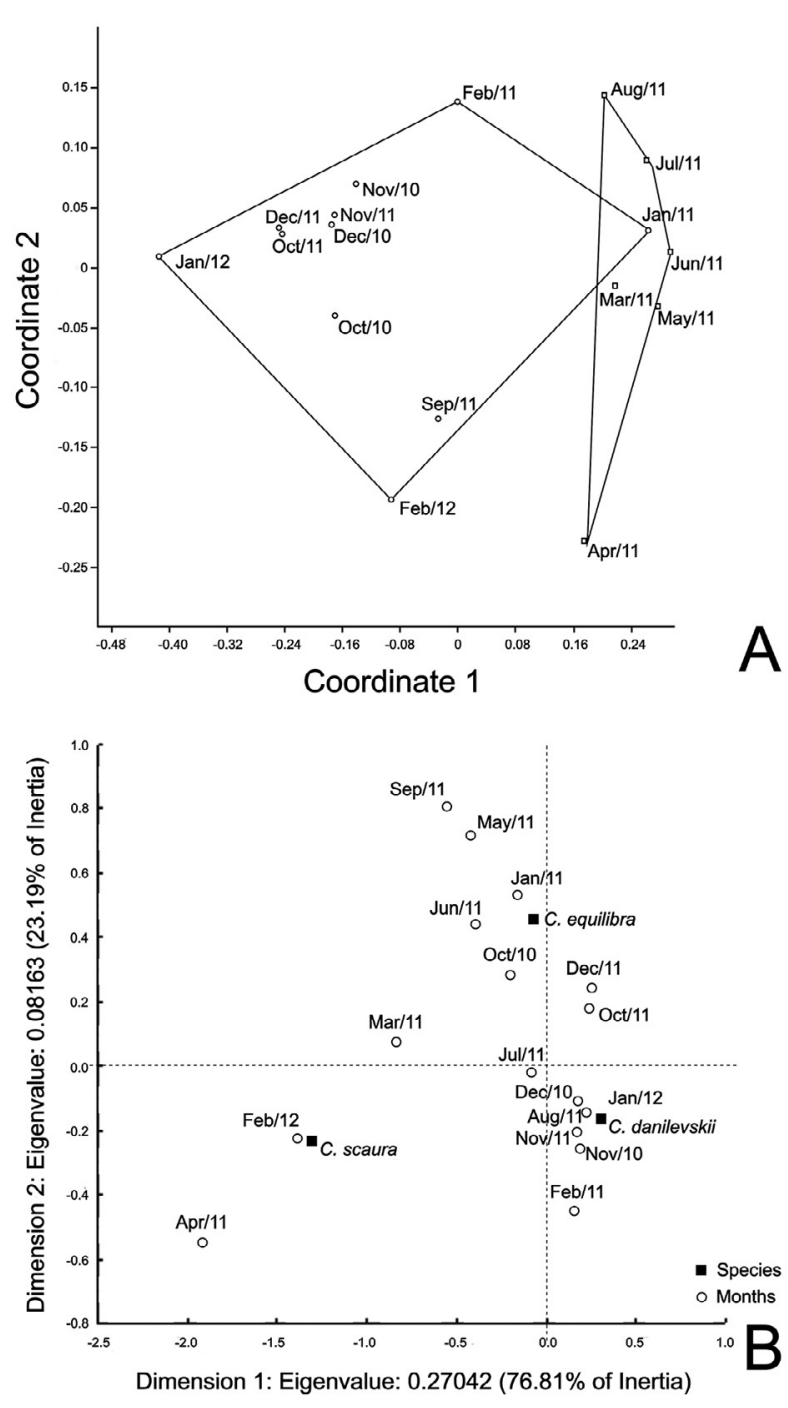

Fig. 6. - The plots of the non-metric multi-dimensional scaling analysis (A) and the correspondence analysis (B), based on the density of the caprellid species and the Sargassum biomass in the studied months in the Ubatuba region, southeastern coast of Brazil.

6A). Density varied across months and seasons (spring-summer and autumn-winter), and this variation was observed in correspondence analysis (Fig. 6B). For C. danilevskii and C. equilibra, the highest density corresponded to late spring and early summer (Figs 5A, B, 6B), while the highest density of C. scaura corresponded mainly to late summer 2012 (Figs 5C and 6B).

\section{DISCUSSION}

\section{Population structure of the caprellids associated with Sargassum}

In this study, a polymodal and non-normal distribution for $C$. danilevskii and C. scaura and a bimodal distribution for C. equilibra were observed. Bimodality or polymodality in the size-frequency distribution may be related to seasonal reproduction of these species through- out the year, which is influenced by recruitment peaks, mortality, migration and/or behavioural differences (Díaz and Conde 1989). This pattern is common among amphipods, such as Cymadusa filosa Savigny, 1816, Mallacoota schellenbergi Ledoyer, 1984 (Appadoo and Myers 2004), Gammarus chevreuxi Sexton, 1913 (Subida et al. 2005) and Hyalella pleoacuta González et al. 2006 (Castiglioni and Bond-Buckup, 2008).

Males of all Caprella species reached larger mean size than females, as is usual for many other caprellids (Guerra-García et al. 2011, Lolas and Vafidis 2013, Garcia et al. 2019). This sexual dimorphism can be related to different energy allocation for growth and the existence of aggressive behaviour between males before copulation (Caine 1991). The maximum size of the caprellids in our study was considerably smaller than that of other populations. Caprella scaura males of a population in southern Italy (Prato et al. 2013) reached 23 $\mathrm{mm}$ and in the present study they reached only 12.96 $\mathrm{mm}$. Caprella equilibra males from the northern Adriatic Sea (Sconfietti and Luparia 1995) reached $19 \mathrm{~mm}$, while in the studied area the maximum male size was $12.53 \mathrm{~mm}$. This difference in body size can be related to local parameters, including water temperature and predation pressure. Comparing C. scaura sizes from different seasons in South Carolina, Foster et al. (2004) recorded larger males in winter than in summer. They suggested that this difference could be related to predation decrease and reduced reproductive activity during colder months. Guerra-García et al. (2011) suggest that other factors such as competition with other species and availability of substrates or food could also be responsible for these differences.

The variety of sizes recorded for ovigerous females in this study has already been observed for Caprella equilibra and Caprella dilatata Krøyer, 1843 in a study conducted in Argentina (Nuñez-Velazquez et al. 2017) and for $C$. equilibra from an estuarine population on the northern coast of Italy (Sconfietti and Luparia 1995). This pattern indicates that all three species in our study have an iteroparous life cycle, i.e. they can reproduce multiple times.

The sex ratio deviated for males as recorded in this study was already observed for other caprellid species, such as Paracaprella tenuis Mayer, 1903 and Pseudaeginella montoucheti Quitete, 1971 (Garcia et al. 2019). The predominance of males suggests an intraspecific competition for females (Powell and Moore, 1991). The sex ratio deviation can also be related to high energetic investment in reproduction by the females (Cardoso and Veloso 1996), which can limit growth and reduce their survival (Thiel 2003).

\section{Temporal dynamics of the caprellids associated with Sargassum}

A density variation throughout the year was recorded for all the species with higher densities in spring and summer. This pattern is the result of favourable conditions in these periods, such as the higher incidence of light and the nutrient availability, which allow for greater growth of macroalgae (Moore et al. 
1997, Moore and Wetzel 200). According to De Paula et al. (2016), the reproductive biology evaluation of the caprellid amphipods of Lázaro Beach indicated a more intense reproduction in autumn and winter. Other caprellid species, such as Paracaprella tenuis and Pseudaeginella montoucheti, which were recorded in the same area as the present study, showed higher densities in winter (Garcia et al. 2019). This indicates possible competitive interactions among those caprellids and Caprella species.

In this study, the period of higher algal biomass (spring-summer) corresponds to the higher densities of Caprella species. The biomass of Sargassum fronds is an important predictor of caprellid densities, in which higher densities of caprellids would be expected in periods with higher algal biomass, and this pattern was also recorded for other caprellids, such as $P$. tenuis and P. montoucheti (Garcia et al. 2019). However, other factors are certainly important to explain caprellid density because the biomass-density correlations were low $\left(\mathrm{r}^{2}<0.20\right)$.

Epibiosis could be one of these factors because it increases habitat complexity (James and Heck 1994) and consequently the availability of resources. In a study conducted just a few miles from the site of the present study (Jacobucci et al. 2009), the densities of some caprellid species were positively related to epiphyte algal load. The accumulation of detritus is enhanced by epiphytes (Heck and Wetstone 1977, Hacker and Steneck 1990, Russo 1990), thus benefiting species that are mainly detritivores such as the Caprella species studied (Guerra-García and Figueroa 2009).

Epiphytes also increases the available surface, favouring colonization of bacteria and microalgae that are food resources for grazers. This biofilm could contribute to the higher mean densities of $C$. danilevskii, which has an opportunistic feeding habit, consuming not only detritus but also microalgae (Guerra-García and Figueroa 2009). Hydrozoan cover in Sargassum fronds can also explain caprellid density variation. In a study conducted at Lázaro Beach, the density of $\mathrm{Ca}$ prella danilevskii and $C$. equilibra species was significantly related to total hydrozoan cover of $S$. cymosum fronds (Cunha et al. 2018).

Wave exposure in the sampling area is another factor that could favour $C$. danilevskii. This species is commonly abundant in areas with higher hydrodynamic levels (Guerra-García and García-Gómez 2001). Caprella danilevskii acquired the ability of attaching to the substrate using gnathopod 1 in a "parallel" posture which reduces displacement by wave action (Takeuchi and Hirano 1995). This "habitat preference" is confirmed in a study conducted on a nearby rock shore with extremely low wave exposure, where $C$. danilevskii showed low densities in comparison with other Caprella species (Jacobucci et al. 2009).

Studies conducted in temperate regions indicated different peaks in reproductive activity. In Mar del Plata harbour (Argentina), higher densities of $C$. equilibra ovigerous females were recorded in summer (Nuñez-Velazquez et al. 2017) and in European (Mediterranean Sea) C. equilibra populations the breeding period occurs in spring and autumn at moderate temperatures and stops in winter (Sconfietti and Luparia 1995). Periodic or more intense reproduction in certain periods of the year seems to characterize the species of Caprella studied, with reproductive peaks coinciding with the coldest months of the year.

The present study indicates that sympatric populations of Caprella danilevskii, C. equilibra and C. scau$r a$ have significant temporal fluctuations, with higher densities in spring and summer that are related to higher algal biomass, but other environmental factors such as epibiosis and wave exposure are certainly important to explain caprellid density variation. Additional field and experimental studies on caprellids will be important to better understand the biology of this still poorly known crustacean group.

\section{ACKNOWLEDGEMENTS}

Thanks to Daniel Silva for the help with algal sampling and all collaborators, interns and volunteers who helped in field work and sample processing. Thanks are also extended to Fundação de Amparo à Pesquisa do Estado de Minas Gerais (FAPEMIG) and Conselho Nacional de Desenvolvimento Científico e Tecnológico Pesquisa $(\mathrm{CNPq})$, which supported this study with scholarships.

\section{REFERENCES}

Ahyong S.T., Lowry J.K., Alonso M., et al. 2011. Subphylum Crustacea Brünich, 1772. In: Zhang Z.-Q. (ed.), Animal biodiversity: An outline of higher-level classification and survey of taxonomic richness. Zootaxa 3148: 165-191. https://doi.org/10.11646/zootaxa.3148.1.33

Appadoo C., Myers A.A. 2004. Reproductive bionomics and life history traits of three gammaridean amphipods, Cymadusa filosa Savigny, Ampithoe laxipodus Appadoo and Myers and Mallacoota schellenbergi Ledoyer from the tropical Indian Ocean (Mauritius). Acta Oecol. 26: 227-238. https://doi.org/10.1016/j.actao.2004.06.002

Barros-Alves S.P., Alves D.F.R., Cobo V.J. 2017. Brachyuran crab (Crustacea, Decapoda) assemblage associated with Sargassum cymosum in southeastern Brazil. Mar. Biodiv. 48: 2043-2055. https://doi.org/10.1007/s12526-017-0730-3

Boos K., Ashton G.V., Cook E.J. 2011. The Japanese skeleton shrimp Caprella mutica (Crustacea, Amphipoda): a global invader of coastal waters. In: Galil B.S., Clack, P.F., et al. (eds) In the wrong place - alien marine crustaceans: distribution, biology and impacts. Springer, Berlin, pp 129-156. https://doi.org/10.1007/978-94-007-0591-3_4

Bynum K.H. 1978. Reproductive biology of Caprella penantis Leach, 1814 (Amphipoda: Caprellidae) in North Carolina, U.S.A. Estuar. Coast. Mar. Sci. 7: 473-485 https://doi.org/10.1016/0302-3524(78)90124-X

Caine E.A. 1991. Reproductive behavior and sexual dimorphism of a caprellid amphipod. J. Crustac. Biol. 11:56-63. https://doi.org/10.2307/1548544

Castiglioni D. S., Bond-Buckup G. 2008. Ecological traits of two sympatric species of Hyalella Smith, 1874 (Crustacea, Amphipoda, Doglielinotidae) from southern Brazil. Acta Oecol. 33: 36-48. https://doi.org/10.1016/j.actao.2007.09.007

Cardoso R.S., Veloso V.G. 1996. Population biology and secondary production of the sandhopper Pseudorchestoidea brasiliensis (Amphipoda: Talitridae) at Prainha Beach, Brazil. Mar. Ecol. Progr. Ser. 142: 111-119. https://doi.org/10.3354/meps142111

Clarke A. 1993. Reproductive trade-offs in caridean shrimps. Funct. Ecol. 7:411-419. https://doi.org/10.2307/2390028 
Cunha A.F., Maruyama P.K., Jacobucci G.B. 2018. Epiphytic hydroids (Cnidaria, Hydrozoa) contribute to a higher abundance of caprellid amphipods (Crustacea, Peracarida) on macroalgae. Hydrobiologia 808: 251-264. https://doi.org/10.1007/s10750-017-3427-5

De Paula D.R., Almeida A.C., Jacobucci G.B. 2016. Reproductive features of sympatric species of Caprella (Amphipoda) on the southeastern Brazilian coast: a comparative study. Crustaceana 89: 933-947. https://doi.org/10.1163/15685403-00003566

Díaz H., Conde J.E. 1989. Population dynamics and life history of the mangrove crab Aratus pisonii (Brachyura, Grapsidae) in a marine environment. Bull. Mar. Sci. 45: 148-163.

Foster J.M., Heard R.W., Knott D.M. 2004. Northern range extensions from Caprella scaura Templeton, 1836 (Crustacea: Amphipoda: Caprellidae) on the Florida Gulf Coast and in South Carolina. Gulf Carib. Res. 16: 65-69. https://doi.org/10.18785/gcr.1601.09

Garcia I.C.P., Cunha K.V.S., Jacobucci G.B. 2019. Population and reproductive biology of two caprellid species (Crustacea: Amphipoda) associated to Sargassum cymosum (Phaeophyta: Fucales) on the southeast coast of Brazil. Nauplius 27: e2019002. https://doi.org/10.1590/2358-2936e2019002

González A.R., Guerra-García J.M., Maestre M.J., et al. 2008. Community structure of caprellids (Crustacea: Amphipoda: Caprellidae) on seagrasses from southern Spain. Helgol. Mar. Res. 62: 189-99. https://doi.org/10.1007/s10152-008-0107-x

Guerra-García J.M. 2001. Habitat use of the caprellidea (Crustacea: Amphipoda) from Ceuta, North Africa. Ophelia 55: 27-38. https://doi.org/10.1080/00785236.2001.10409471

Guerra-García J.M., Figueroa J.M.T. 2009. What do caprellids (Crustacea: Amphipoda) feed on? Mar. Biol. 156: 1881-1890. https://doi.oro/10.1007/s00227-009-1220-3

Guerra-García J.M., García-Gómez J.C. 2001. The spatial distribution of Caprellidea (Crustacea: Amphipoda): a stress bioindicator in Ceuta (North Africa, Gibraltar area). Mar. Ecol. 22: 357-67. https://doi.org/10.1046/j.1439-0485.2001.01757.x

Guerra-García J.M., Ros M., Dugo-Cota A., et al. 2011. Geographical expansion of the invader Caprella scaura (Crustacea: Amphipoda: Caprellidae) to the East Atlantic coast. Mar. Biol. 158: 2617-2622 https://doi.org/10.1007/s00227-011-1754-z

Guerra-García J.M., Hachero-Cruzado I., González-Romero P., et al. 2016. Towards integrated multi-trophic aquaculture: lessons from caprellids (Crustacea: Amphipoda). PLoS ONE 11: e154776. https://doi.org/10.1371/journal.pone.0154776

Hacker S.D., Steneck R.S. 1990. Habitat architecture and body-size-dependent habitat selection of a phytal amphipod. Ecology 71: 2269-2285. https://doi.org/10.2307/1938638

Heck K.L.Jr., Wetstone G.S. 1977. Habitat complexity and invertebrate species richness and abundance in tropical seagrass meadows. J. Biogeogr. 4: 135-142. https://doi.org/10.2307/3038158

Hutchinson G.E. 1981. Introducción a la ecologia de pobliaciones. Barcelona, Blume, 492p.

Imada K., Kikuchi, T. 1984. Studies on some reproductive traits of three caprellids (Crustacea: Amphipoda) and their seasonal fluctuations in the Sargassum bed. Publ. Amakusa Mar. Biol. Lab. 7: 151-172.

Jacobucci G.B., Leite F.P.P. 2002. Distribuição vertical e flutuação sazonal da macrofauna vágil associada a Sargassum cymosum C. Agardh, na praia do Lázaro, Ubatuba, São Paulo, Brasil. Rev. Bras. Zool. 19: 87-100. https://doi.org/10.1590/S0101-81752002000500004

Jacobucci G.B., Moretti D., Silva E.M., et al. 2002. Caprellid amphipods on Sargassum cymosum (Phaeophyta): depth distribution and population biology. Nauplius 10: 27-36.

Jacobucci G.B., Tanaka M.O., Leite F.P.P. 2009. Temporal variation of amphipod assemblages associated with Sargassum filipendula (Phaeophyta) and its epiphytes in a subtropical shore. Aquatic Ecol. 43: 1031-1040. https://doi.org/10.1007/s10452-009-9230-2
Jacobucci G.B., Vieira E.A., Leite F.P.P. 2018. Influence of a narrow depth gradient on the spatial structure of Sargassum peracarid assemblages in Southeastern Brazil. Mar. Biodiver. 49: 1001-1011. https://doi.org/10.1007/s12526-018-0885-6

James P.L., Heck K.L.Jr. 1994. The effects of habitat complexity and light intensity on ambush predation within a simulated seagrass habitat. J. Exp. Mar. Biol. Ecol. 176: 187-200. https://doi.org/10.1016/0022-0981(94)90184-8

Lacerda M.B., Masunari S. 2011. Chave de identificação para caprelídeos (Crustacea, Amphipoda) do litoral dos Estados do Paraná e de Santa Catarina. Biota Neotrop. 11: 365- 376. https://doi.org/10.1590/S1676-06032011000300030

Lolas A., Vafidis D. 2013. Population dynamics of two caprellid species (Crustacea: Amphipoda: Caprellidae) from shallow hard bottom assemblages. Mar. Biodiver. 43: 227-236. https://doi.org/10.1007/s12526-013-0149-4

Martin-Smith K.M. 1993. Abundance of mobile epifauna: the role of habitat complexity and predation by fishes. J. Exp. Mar. Biol. Ecol. 174: 243-260. https://doi.org/10.1016/0022-0981(93)90020-O

Martínez J., Adarraga I. 2008. First record of invasive caprellid Caprella scaura Templeton, 1836 sensu lato (Crustacea: Amphipoda: Caprellidae) from the Iberian Peninsula. Aquat. Invasions 3: 165-171. https://doi.org/10.3391/ai.2008.3.2.6

Mauro F.M., Serejo, C.S. 2015. The family Caprellidae (Amphipoda: Caprelloidea: Caprellidae) from Campos Basin, Southwestern Atlantic, with a key of species occurring in Brazil. Zootaxa 4006: 103-127. https://doi.org/10.11646/zootaxa.4006.1.5

Moore K.A., Wetzel R.L. 2000. Seasonal variations in eelgrass (Zostera marina L.) responses to nutrient enrichment and reduced light availability in experimental ecosystems. J. Exp. Mar. Biol. Ecol. 244: 1-28. https://doi.org/10.1016/S0022-0981(99)00135-5

Moore K.A., Wetzel R.L., Orth R.J. 1997. Seasonal pulses of turbidity and their relations to eelgrass (Zostera marina L.) survival in an estuary. J. Exp. Mar. Biol. Ecol., 215: 115134 https://doi.org/10.1016/S0022-0981(96)02774-8

Nuñez-Velazquez S., Rumbold C.E., Obenat S.M. 2017. Population dynamics of Caprella dilatata and Caprella equilibra (Peracarida: Amphipoda) in a Southwestern Atlantic harbour. Mar. Biol. Res. 13: 888-898. https://doi.org/10.1080/17451000.2017.131710

Ohji M., Arai T., Miyazaki N. 2002. Effects of tributyltin exposure in the embryonic stage on sex ratio and survival rate in the caprellid amphipod Caprella danilevskii. Mar. Ecol. Progr. Ser. 235: 171-176. https://doi.org/10.3354/meps235171

Paula E.D., Oliveira-Filho E. 1980. Aspectos fenológicos de duas populações de Sargassum cymosum (Phaeophyta - Fucales) do litoral de São Paulo, Brasil. Bol. Bot. 8: 21-39. https://doi.org/10.11606/issn.2316-9052.v8i0p21-39

Powell R., Moore P.G. 1991. The breeding cycles of females of seven species of amphipod (Crustacea) from the Clyde Sea area. J. Nat. Hist. 25: 435-479. https://doi.org/10.1080/00222939100770291

Prato E., Parlapiano I., Biandolino F. 2013. Seasonal fluctuations of some biological traits of the invader Caprella scaura (Crustacea: Amphipoda: Caprellidae) in the Mar Piccolo of Taranto (Ionian Sea, southern Italy). Sci. Mar. 77: 169-78. https://doi.org/10.3989/scimar.03631.21B

Ros M., Guerra-García J., Navarro-Barranco C., et al. 2014. The spreading of the non-native caprellid (Crustacea: Amphipoda) Caprella scaura Templeton, 1836 into southern Europe and northern Africa: a complicated taxonomic history. Mediterr. Mar. Sci. 15: 145-155. https://doi.org/10.12681/mms.469

Ros M., Vázquez-Luis M., Guerra-García J.M. 2015. Environmental factors modulating the extent of impact in coastal invasions: the case of a widespread invasive caprellid (Crustacea: Amphipoda) in the Iberian Peninsula. Mar. Pollut. Bull. 98: 247-258 https://doi.org/10.1016/j.marpolbul.2015.06.041

Russo A.R. 1990. The role of seaweed complexity in structuring Hawaiian epiphytal amphipod communities. Hydrobiologia 194: 1-12. https://doi.org/10.1007/BF00012107 
Santos S., Negreiros-Fransozo M.L., Fransozo A. 1995. Estructura poblacional de Portunus spinimanus Latreille, 1819 (Crustacea, Brachyura, Portunidade) en La Enseada de la Fortaleza, Ubatuba (SP). Rev. Invest. Mar. 16: 37-43.

Sconfietti R., Luparia P. 1995. Population ecology of the amphipod Caprella equilibra Say in a lagoon estuary (Northern Adriatic Sea, Italy). Mar. Ecol. 16: 1-11. https://doi.org/10.1111/j.1439-0485.1995.tb00390.x

Servello G., Andaloro F., Azzurro E., et al. 2019. Marine alien species in Italy: A contribution to the implementation of descriptor D2 of the marine strategy framework directive. Mediterr. Mar. Sci. 20: 1-48. https://doi.org/10.12681/mms.18711

Subida M.D., Cunha M.R., Moreira M.H. 2005. Life history, reproduction, and production of Gammarus chevreuxi (Amphipoda: Gammaridae) in the Ria de Aveiro, northwestern Portugal. J. N. Am. Benthol. Soc. 24: 82-100.

https://doi.org/10.1899/0887-3593(2005)024<0082:LHRA $\mathrm{PO}>2.0 . \mathrm{CO} ; 2$

Széchy M.T.M., Paula E.J. 2000. Padrões estruturais quantitativos de bancos de Sargassum (Phaeophyta, Fucales) do litoral dos Estados do Rio de Janeiro e de São Paulo, Brasil. Rev. Bras. Bot. 23: 121-132. https://doi.org/10.1590/S0100-84042000000200002

Takeuchi I., Hirano R. 1991. Growth and reproduction of $\mathrm{Ca}$ prella danilevskii (Crustacea: Amphipoda) reared in the laboratory. Mar. Biol. 110: 391-397. https://doi.org/10.1007/BF01344358

Takeuchi I., Hirano R. 1995. Clinging behaviour of the epifaunal caprellids (Amphipoda) inhabiting the Sargassum zone on the Pacific Coast of Japan, with its evolutionary implications. J. Crust. Biol. 15: 481-492.

https://doi.org/10.1163/193724095X00497
Takeuchi I., Kuwabara R., Hirano R., et al. 1987. Species composition of the Caprellidea (Crustacea: Amphipoda) of the Sargassum zone on the Pacific coast of Japan. Bull. Mar. Sci. 4: 253-267.

Thiel M. 2003. Extended parental care in crustaceans: an update. Rev. Chil. Hist. Nat. 76: 205-218. https://doi.org/10.4067/S0716-078X2003000200007

Thiel M., Guerra-García J.M., Lancellotti D.A., et al. 2003. The distribution of littoral caprellids (Crustacea: Amphipoda: Caprellidea) along the Pacific coast of continental Chile. Rev. Chil. Hist. Nat. 76: 203-218. https://doi.org/10.4067/S0716-078X2003000200014

Vázquez-Luis M., Sanchez-Jerez P., Bayle-Sempere J.T. 2009. Comparison between amphipod assemblages associated with Caulerpa racemosa var. cylindracea and those of other Mediterranean habitats on soft substrate. Estuar. Coast. Shelf Sci. 84: 161-70. https://doi.org/10.1016/j.ecss.2009.04.016

Wilson K., Hardy I.C.W. 2002. Statistical analysis of sex ratios: an introduction. In: Hardy I.C.W. (ed) Sex ratios: concepts and research methods. Cambridge University Press, Cambridge, pp 48-92. https://doi.org/10.1017/CBO9780511542053.004

Woods C.M.C. 2009. Caprellid amphipods: an overlooked marine finfish aquaculture. Aquaculture 289: 199-211. https://doi.org/10.1016/j.aquaculture.2009.01.018

Zar J.H. 2010. Biostatistical Analysis. 5th ed. Upper Saddle River: Prentice-Hall, 944 pp. 